\title{
Chronic exposure to nitrate significantly reduces growth and affects the health status of juvenile Nile tilapia (Oreochromis niloticus L.) in recirculating aquaculture systems
}

\author{
Monsees, Hendrik ${ }^{1}$; Klatt, Laura ${ }^{2}$; Kloas, Werner ${ }^{3}$; Wuertz, Sven ${ }^{4}$
}

DOI

10.1111/are.13174

Original publication date

6. August 2016 (Version of record online)

\section{Document version}

Accepted version

\section{Published in}

Aquaculture Research

\section{Citation (Vancouver)}

Monsees H, Klatt L, Kloas W, Wuertz S. Chronic exposure to nitrate significantly reduces growth and affects the health status of juvenile Nile tilapia (Oreochromis niloticus L.) in recirculating aquaculture systems. Aquac Res. 2017;48(7):3482-92.

\footnotetext{
Author affiliation

1: Leibniz-Institute of Freshwater Ecology and Inland Fisheries, Berlin, Germany; Albrecht Daniel Thaer-Institute of Agricultural and Horticultural Sciences, Humboldt University, Berlin, Germany. (D) https://orcid.org/0000-0003-2935-1106

2: Leibniz-Institute of Freshwater Ecology and Inland Fisheries, Berlin, Germany; Albrecht Daniel Thaer-Institute of Agricultural and Horticultural Sciences, Humboldt University, Berlin, Germany

3: Leibniz-Institute of Freshwater Ecology and Inland Fisheries, Berlin, Germany; Albrecht Daniel Thaer-Institute of Agricultural and Horticultural Sciences, Humboldt University, Berlin, Germany

4: Leibniz-Institute of Freshwater Ecology and Inland Fisheries, Berlin, Germany. (D) https://orcid.org/0000-0002-8190-2684
} 
1 Chronic exposure to nitrate significantly reduces growth and affects the health status of

2 juvenile Nile tilapia (Oreochromis niloticus $\mathbf{L}$.) in recirculating aquaculture systems

3

4 Hendrik Monsees ${ }^{\mathrm{a}, \mathrm{b}}$, Laura Klatt ${ }^{\mathrm{a}, \mathrm{b}}$, Werner Kloas ${ }^{\mathrm{a}, \mathrm{b}}$, Sven Wuertz ${ }^{\mathrm{a}, \mathrm{b}}$

5

$6{ }^{a}$ Leibniz-Institute of Freshwater Biology and Inland Fisheries, Müggelseedamm 310, 12587

7 Berlin, Germany

8 b Albrecht Daniel Thaer-Institute of Agricultural and Horticultural Sciences, Humboldt

9 University Berlin, Unter den Linden 6, 10099 Berlin, Germany

10

13 Correspondence: H Monsees, Leibniz-Institute of Freshwater Ecology and Inland Fisheries, 14 Müggelseedamm 310, 12587 Berlin, Germany, Email: h.monsees@igb-berlin.de

16 Key words: feed conversion; specific growth rate; methemoglobin, gill histology, nitrate; nitrite 
Abstract

27 Studies on chronic or acute toxicity of nitrogen species on fish in recirculating aquaculture 28 systems (RAS) usually focused on adverse effects of total ammonia nitrogen (TAN: sum of $\mathrm{NH}_{3}$

$\left.29+\mathrm{NH}_{4}^{+}\right)$and nitrite $\left(\mathrm{NO}_{2}^{-}\right)$, while underestimating the potential effects of high nitrate 30 accumulation on growth and health status of fish. In our study, Nile tilapia (Oreochromis 31 niloticus) were exposed to five different nitrate concentrations $\left(0,10,100,500\right.$ and $1000 \mathrm{mg} \mathrm{L}^{-1}$

$32 \mathrm{NO}_{3}{ }^{-} \mathrm{N}$ ) over 30 days. Growth parameters (feed conversion ratio: FCR, specific growth rate:

33 SGR, hepatosomatic index: HSI), blood samples (concentrations of hemoglobin, methemoglobin,

34 plasma $\mathrm{NO}_{2}{ }^{-} / \mathrm{NO}_{3}{ }^{-}$) and the histology of the gills were studied to evaluate growth and health 35 status of the fish. At the highest nitrate concentration, the fish showed significantly reduced 36 growth and impaired health status (SGR, FCR, plasma $\mathrm{NO}_{2}{ }^{-} / \mathrm{NO}_{3}{ }^{-}$, hemoglobin- and 37 methemoglobin concentration), demonstrating that too high nitrate concentrations can negatively 38 influence tilapia production in RAS. Here, we recommend not exceeding concentrations of

$39500 \mathrm{mg} \mathrm{L}^{-1} \mathrm{NO}_{3}{ }^{-} \mathrm{N}$ in juvenile tilapia culture to ensure an optimal health and growth status of the 40 fish, since below that concentration no effects on the tilapia have been observed.

\section{Introduction}

43 Recirculating aquaculture systems (RAS) have been rapidly evolving over the last two decades

44 and are envisioned a great potential with regard to a sustainable aquaculture development due to 45 the efficient use of water and space as well as minor environmental impact (Gutierrez-Wing \& 46 Malone 2006). However, a major drawback of RAS is the accumulation of waste products such 47 as nitrate after biofiltration. As a consequence of improved recirculation technology and 48 subsequently decreasing water exchange, waste products such as nutrients are accumulating in 49 the process water (van Rijn 2013). Compared to open aquaculture systems like ponds, net cages 
50 or semi-closed systems where these products are of minor relevance to the cultured species due to

51 high water exchange, concentrations may exceed critical levels impacting welfare as well as

52 performance of the fish. This is particularly relevant for aquaponics, where high nitrate

53 concentrations originating from a RAS-based fish production are desirable to fertilize the plants

54 in the hydroponic unit. Here, nitrate concentrations in the range of $150-230 \mathrm{mg} \mathrm{L}^{-1} \mathrm{NO}_{3}{ }^{-} \mathrm{N}$ are

55 recommended e.g. for the hydroponic production of tomatoes, cucumbers and peppers

56 (Lattauschke 2004)

57 Biofiltration in RAS is necessary to convert toxic total ammonia nitrogen (TAN) via nitrite to 58 nitrate (Timmons, Holder \& Ebeling 2006). Based on the experience in open systems and the 59 respective concentrations, nitrate has been considered harmless to the fish (Rakocy, Masser \& 60 Losordo 2006) and only limited attention was directed to the adverse effects of nitrate in the past.

61 However, in contrast to ponds and other open systems, nitrate can accumulate to concentrations

62 of up to $1000 \mathrm{mg} \mathrm{L}^{-1} \mathrm{NO}_{3}{ }^{-} \mathrm{N}$ in RAS (van Rijn 2010). Therefore, potential chronic effects on

63 growth and health of fish become more likely. Furthermore, problems interfering with the

64 production efficiency may emerge due to reduced growth performance caused by high nitrate

65 concentrations.

66 The conversion of hemoglobin to methemoglobin has been reported as the main mechanism of

67 nitrate toxicity on aquatic animals (Jensen 1996; Scott \& Crunkilton 2000; Cheng \& Chen 2002),

68 but alternative modes of action (MOA) have been discussed including pathological impairment of

69 the gills, immune suppression and endocrine effects on the thyroid system as well as on

70 androgens and estrogens (Camargo, Alonso \& Salamanca 2006; Davidson, Good, Welsh \&

71 Summerfelt 2014; Hamlin, Moore, Edwards, Larkin, Boggs, High, Main \& Guillette 2008,

72 Freitag, Thayer, Leonetti, Stapleton \& Hamlin 2015). In a 30 day trial, nitrate modulated the

73 conversion of steroids at $57 \mathrm{mg} \mathrm{L}^{-1} \mathrm{NO}_{3}^{-}-\mathrm{N}$, affecting key players - testosterone, 11- 
74 ketotestosterone and estradiol - in the endocrine regulation of growth and reproduction (Hamlin 75 et al. 2008) and concentrations as low as $10 \mathrm{mg} \mathrm{L}^{-1} \mathrm{NO}_{3}{ }^{-} \mathrm{N}$ raised testosterone in Atlantic salmon

76 (Freitag et al. 2015). In mosquitofish, embryonal dry weight was reduced and reproductive

77 behavior of mature females was affected at minimal concentrations of $5 \mathrm{mg} \mathrm{L}^{-1} \mathrm{NO}_{3}{ }^{-} \mathrm{N}$ 78 (Edwards, Miller \& Guillette 2006). Moreover, elevated nitrate concentrations up to $110 \mathrm{mg} \mathrm{L}^{-1}$ $79 \mathrm{NO}_{3}{ }^{-} \mathrm{N}$ lead to a decrease in the thyroid hormones $\mathrm{T} 3$ and $\mathrm{T} 4$ in rats (Eskiocak, Dundar, Basoglu $80 \&$ Altaner 2005). Impact on swimming performance and survival in juvenile rainbow trout has 81 already been reported at $91 \mathrm{mg} \mathrm{L}^{-1} \mathrm{NO}_{3}^{-} \mathrm{-N}$ (Davidson et al. 2014). Still, substantially reduced 82 growth performance might be the most relevant for the farmer in terms of economic impact. At 83 increasing nitrate concentrations, linear decrease in specific growth rate (SGR) was observed in 84 turbot (Scophthalmus maximus) resulting in a dramatically reduced SGR (30\%) at $500 \mathrm{mg} \mathrm{L}^{-1}$

$85 \mathrm{NO}_{3}{ }^{-} \mathrm{N}$ (van Bussel, Schroeder, Wuertz \& Schulz 2012). Similarly, Schram, Roques, Abbink, 86 Yokohama, Spanings, de Vries, Bierman, van de Vis \& Flik (2014, a) observed reduced growth 87 performance in African catfish (Clarias gariepinus) at nitrate concentrations $>140 \mathrm{mg} \mathrm{L}^{-1} \mathrm{NO}_{3}^{-}$88 N. Consequently, adverse effects need to be evaluated for one of the most important species in 89 intensive aquaculture, where concentrations above $100 \mathrm{mg} \mathrm{L}^{-1} \mathrm{NO}_{3}^{-}-\mathrm{N}$ are regularly observed and 90 thus may be relevant upon chronic exposure.

91 In contrast, acute toxicity of nitrate in fish is often observed at extreme concentrations, where $9296 \mathrm{~h}$ LC50 were observed between $1,250 \mathrm{mg} \mathrm{L}^{-1} \mathrm{NO}_{3}{ }^{-} \mathrm{N}$ and $1,400 \mathrm{mg} \mathrm{L}^{-1} \mathrm{NO}_{3}^{-}-\mathrm{N}$ e.g. in 93 rainbow trout (Oncorhynchus mykiss), channel catfish (Ictalurus punctatus) and Chinook salmon 94 (Oncorhynchus tshawytscha) in separate studies (Tomasso \& Carmichael 1986; Colt \& 95 Tchobanoglous 1976; Westin 1974). Despite the importance of tilapia aquaculture globally (FAO 96 2012), no data on chronic effects of nitrate exposure and safe threshold concentrations have been 97 published so far. In addition, the uptake of nitrate in fish is not yet comprehensively described, 
98 but essential to understand nitrate toxicity in fish. Compared to $\mathrm{NH}_{3}$ or $\mathrm{NO}_{2}^{-}$nitrate uptake is

99 presumably low as a result of low branchial permeability towards nitrate (Stormer, Jensen \&

100 Rankin 1996). Still, relatively high plasma concentrations of $\mathrm{NO}_{\mathrm{x}}\left(\right.$ sum of $\mathrm{NO}_{2}{ }^{-}$and $\mathrm{NO}_{3}{ }^{-}$) have

101 been reported upon nitrate exposure (Schram et al, 2014 a,b; Stormer et al., 1996). Consequently,

102 alternative uptake routes and sites may be involved.

103 The objective of the present study was to identify potential effects of high nitrate concentrations

104 on growth and health status of juvenile Nile tilapia. Therefore an exposure experiment was

105 conducted with juvenile Nile tilapia to assess the impact of nitrate in intensive aquaculture. Based

106 on the results we give a recommendation for safe levels of nitrate in the production of juvenile

107 Nile tilapia. In a second experiment, the reduction of nitrate to nitrite in the stomach juice was

108 studied in vitro over time to clarify if nitrate conversion and subsequent nitrite uptake is an

109 alternative uptake route to direct uptake of nitrate, considering the plasma concentrations of

110 nitrite and nitrate observed in vivo.

111

\section{Material and Methods}

\section{Experimental setup}

114 We conducted an experimental $\mathrm{NO}_{3}{ }^{-}$exposure of juvenile tilapia (total length $8.8 \pm 0.48 \mathrm{~cm}$, wet

115 weight $13.5 \pm 2.5 \mathrm{~g})$ at concentrations of $0,10,100,500$ and $1000 \mathrm{mg} \mathrm{L}^{-1} \mathrm{NO}_{3}-\mathrm{N}(0,0.7,7,36$,

$11670 \mathrm{mM}$ ) over a $30 \mathrm{~d}$ period in a continuous flow-through system. Tilapia were individually

117 stocked to forty $9 \mathrm{~L}$ glass aquaria $(30 \times 20 \times 14.5 \mathrm{~cm})$ with an overflow providing $7 \mathrm{~L}$ of rearing

118 volume (flow rate $50 \mathrm{~L} / \mathrm{d}$ ). All aquaria were placed in a water bath and aerated, assuring a

119 constant temperature of $27.3^{\circ} \pm 0.3^{\circ} \mathrm{C}\left(\min 26.0^{\circ} \mathrm{C}, \max 28.9^{\circ} \mathrm{C}\right)$ and $7.8 \pm 0.3 \mathrm{mg} / \mathrm{L} \mathrm{O}_{2}(100 \%$

$120 \mathrm{O}_{2}$ ). Fish were fed a commercial food (Aller Futura Ex, Emsland-Aller Aqua, Germany) at $1.5 \%$

121 of their body weight per day. 
122 After acclimatization for one week, respective concentrations were established by flow controlled

123 assembly consisting of a peristaltic pump, a rotameter flow gauge, a needle valve and a mixing

124 chamber, diluting a 100fold stock solution with prefiltered, temperature conditioned tap water

125 (Lutz, Kloas, Springer, Holden, Wolf, Krueger, \& Hosmer 2008). The stock solution was

126 formulated with $\mathrm{NaNO}_{3}$ and $\mathrm{KNO}_{3}$ at $\mathrm{Na}^{+} / \mathrm{K}^{+}$weight ratio of $6.2: 1$ considering the mean ratio in

127 the Nile (Zimmermann-Timm 2011; Dekov, Komy, Araujo, Van Put \& Van Grieken 1997; Komy

128 \& El-Samahy 1995) to avoid disturbances in cellular homeostasis (van Bussel et al. 2012).

$129 \mathrm{NaNO}_{3}$ and $\mathrm{KNO}_{3}$ were food quality grade (CHEM-DIS, Eisenberg, Germany). Each mixing

130 chamber supplied four aquaria, referred to as cluster. For each treatment, there where two clusters

131 assessing eight fish in total. Flow rates of nitrate stock solutions were controlled and adjusted

132 twice a day, flow rates of tap water were controlled on a weekly basis. Temperature, $\mathrm{pH}$ and

133 oxygen concentration were determined daily with a portable multimeter (HQ40d multi, Hach

134 Lange GmbH, Germany). Salinity was measured three times over the experimental period with a

135 portable meter (WTW LF92, WTW GmbH, Weilheim, Germany). The experiment was

136 conducted in compliance with the local animal welfare committee (LAGESO G0367/12).

137 Concentrations $\left(\mathrm{mg} \mathrm{L}^{-1}-\mathrm{N}\right)$ of $\mathrm{TAN}, \mathrm{NO}_{2}{ }^{-}$and $\mathrm{NO}_{3}{ }^{-}$in the water were determined every second 138 day by the cadmium reduction method, the diazotization method and the ammonia salicylate 139 method using a spectrophotometer DR3900 (Hach Lange GmbH, Germany).

\section{Sampling}

141 After 30 days, fish were killed and blood samples were taken from the caudal vein with 142 heparinized syringes. Samples for the determination of hemoglobin were kept on ice and 143 analyzed within $3 \mathrm{~h}$. For methemoglobin, whole blood samples were shock frozen and stored at $14480^{\circ} \mathrm{C}$. Blood plasma was obtained by centrifugation (5000 $\left.\mathrm{g}, 2 \mathrm{~min}\right)$, shock frozen and stored at $14580^{\circ} \mathrm{C}$. Fish were weighed to the nearest $0.1 \mathrm{~g}$ and length was recorded to the nearest of $1 \mathrm{~mm}$, 
146 liver to the nearest of $1 \mathrm{mg}$. The HSI was calculated as HSI = (liver weight / final weight of fish)

$147 * 100$. For histology, the fourth right gill arch was dissected and fixed in $10 \%$ phosphate buffered 148 formaldehyde solution (Histofix, Carl Roth, Germany).

\section{Plasma concentrations of $\mathrm{NO}_{2}{ }^{-}$and $\mathrm{NO}_{3}{ }^{-}$}

150 We measured the sum of nitrite and nitrate $\left(\mathrm{NO}_{\mathrm{x}}\right)$ as well as nitrite in the plasma using the 151 nitrate/nitrite colorimetric assay kit (Cayman, USA) according to the user's manual. Briefly, for

$152 \mathrm{NO}_{\mathrm{x}}$ and $\mathrm{NO}_{2}{ }^{-}$determination, plasma was diluted 1:20 prior measurement. Absorbtion was 153 determined at $530 \mathrm{~nm}$ with an Infinite M200 microplate reader (Tecan Trading AG, Switzerland).

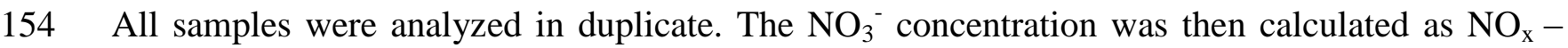
$155 \mathrm{NO}_{2}$.

\section{Hemoglobin and methemoglobin determination}

157 Total hemoglobin was determined within $3 \mathrm{~h}$ upon sampling with a diagnostic hemoglobin kit

158 (DiaSys Diagnostic Systems, Germany) and calculated from a standard dilution series (12 g/dL 159 hemoglobin standard, HEM QS, Diaglobal, Germany) as described in Wuertz, Schulze,

160 Eberhardt, Schulz \& Schroeder (2013). For the methemoglobin concentration the ratio of Meth-

$161 \mathrm{Hb}$ and total-Hb was determined using the cyan ferrocyancomplex method according to Hegesh, 162 Gruener, Cohen, Bochkovsky \& Shuval (1970). Briefly, $20 \mu \mathrm{L}$ blood was incubated (15 min) in 1 $163 \mathrm{~mL}$ pure water. After addition of $600 \mu \mathrm{L}$ saponin solution (1\% saponin, $14 \mathrm{mM} \mathrm{Na} 2 \mathrm{HPO}_{4}, 42$ $164 \mathrm{mM} \mathrm{KH}_{2} \mathrm{PO}_{4}, \mathrm{pH}$ 6.6) and vortexing, cell debris were separated by centrifugation (10 min, 3000 $165 \mathrm{~g}$ ). Samples were analyzed in duplicates, measuring the absorption at $633 \mathrm{~nm}$ in (A1) $250 \mu \mathrm{L}$ 166 supernatant, (A2) after the addition of $5 \mu \mathrm{L} 1 \% \mathrm{KCN}$ and incubation for $10 \mathrm{~min}$, in (A3) $250 \mu \mathrm{L}$ 167 supernatant after addition of $5 \mu \mathrm{L} \mathrm{K}_{4}\left[\mathrm{Fe}(\mathrm{CN})_{6}\right]$, followed by an addition of $5 \mu \mathrm{L} 1 \% \mathrm{KCN}$ and 168 incubation for $10 \mathrm{~min}(\mathrm{~A} 4)$. Total $\mathrm{Hb}: \mathrm{MetHb}$ was calculated as (A1-A2)/(A3-A4). 
170 After fixation in phosphate-buffered formalin for approximately $24 \mathrm{~h}$ at $4^{\circ} \mathrm{C}$, samples were

171 transferred to embedding cassettes and washed three times with $0.1 \mathrm{M}$ phosphate buffer [0.1 M

$172 \mathrm{NaH}_{2} \mathrm{PO}_{4}, 0.1 \mathrm{M} \mathrm{Na}_{2} \mathrm{HPO}_{4}, \mathrm{pH}$ 7.3]. The last washing step was carried out overnight. Samples

173 were dehydrated with successive washes of EtOH $(70 \%, 96 \%, 100 \%, 100 \%)$ for $1 \mathrm{~h}$ each.

174 Preinfiltratation was carried out with a 1:1 ethanol Technovit 7100 solution for $1 \mathrm{~h}$, followed by

175 infiltration in $100 \mathrm{~mL}$ Technovit 7100 with $1 \mathrm{~g}$ hardener (dissolved within 5 min) on a shaker

176 overnight (approx. $12 \mathrm{~h}$ ). Samples were then transferred to Histoform $\mathrm{S}$, orientated and the

177 polymerization was initiated with $1 \mathrm{ml}$ hardener 2 in $15 \mathrm{~mL}$ solution and embedded within five

178 minutes. After the polymerization, blocking of the embedded specimen was carried out with

179 Technovit 3040. Samples were cut to $2 \mu \mathrm{m}$ slices with a rotary microtome (Jung RM 2065; Leica,

180 Germany) transferred to microscope slides, and hematoxylin-eosin (HE) stained.

181 Gills were analysed at $400 \times$ magnification with the PALM Robo Imaging Software and a Zeiss

182 AxioObserver microscope attached to a CCD camera (Carl Zeiss MicroImaging GmbH,

183 Germany). Within 5 primary filaments per sample a total of 100 secondary lamellae were

184 considered for each fish and histopathological changes were recorded. Dorsal and ventral

185 secondary lamellae were considered in same amounts. Histopathological changes of the

186 secondary lamellae and interlamellar spaces of the primary filament in-between were recorded

187 according to Monteiro, Rocha, Fontainhas-Fernandes \& Sousa (2008).

\section{Conversion of nitrate in stomach content of tilapia}

189 To examine the potential conversion of nitrate in vitro, the stomach content (1.5 ml per fish) of

190 adult tilapia (550-650 g, $\mathrm{n}=20$ ) was collected after sacrifice. After centrifugation (16000 $\mathrm{g}$ for

$1912 \mathrm{~min}$ ), nitrate stock solution $\left(3.035 \mathrm{~g} \mathrm{NaNO}_{3}\right.$ in $10 \mathrm{~mL}$ ) was added to the supernatant (gastric

192 juice) to reach a target concentration of $1000 \mathrm{mg} \mathrm{L}^{-1} \mathrm{NO}_{3}^{-}-\mathrm{N}$. Samples (gastric juice and solids) 
193 were mixed gently with the tip of the pipette and incubated at room temperature for 5, 45, 90 and

$194150 \mathrm{~min}$ respectively. After incubation, samples were centrifuged (16000 g for $5 \mathrm{~min})$ and 195 supernatant was analyzed for $\mathrm{NO}_{2}{ }^{-}$and $\mathrm{NO}_{3}{ }^{-}\left(\mathrm{mg} \mathrm{L}^{-1}-\mathrm{N}\right)$ as described earlier.

\section{Statistical analysis}

197 Data are presented as means \pm standard deviation (SD) of $\mathrm{n}$ samples. Statistical analysis was 198 performed using Graphpad Prism (GraphPad Software Inc., La Jolla, USA). Data were tested for 199 normality (Shapiro-Wilk) and equal variance (Kruskal-Wallis). Multiple comparisons were 200 carried out by non-parametric Dunn's test $(\mathrm{p}<0.05)$. Results for gill histology were expressed in

201 percent and, prior to statistics, transformed with an arcsine-square root transformation.

\section{Results}

\section{Survival and growth performance}

204 During the experiment, mortality was only observed in the highest treatment group (1000 $\mathrm{mg} \mathrm{L}^{-}$

$\left.205{ }^{1} \mathrm{NO}_{3}{ }^{-} \mathrm{N}\right)$, where three fish died. No further analyses were carried out on these fish. There was a 206 general decrease in the specific growth rate (SGR) observed with increasing $\mathrm{NO}_{3}{ }^{-}$concentration 207 (Fig.1). Lowest SGR (1.1\% d $\left.\mathrm{d}^{-1} \pm 0.1\right)$ was recorded at $1000 \mathrm{mg} \mathrm{L}^{-1} \mathrm{NO}_{3}^{-}-\mathrm{N}$, which was 208 significantly lower compared to the control group ( $\mathrm{P}<0.01$, non-parametric Dunn`s). The SGR 209 already decreased at $100 \mathrm{mg} \mathrm{L}^{-1} \mathrm{NO}_{3}{ }^{-}-\mathrm{N}$ group, though not significantly different from control 210 fish. The feed conversion ratio (FCR) increased with increasing nitrate concentration (Fig.2).

211 Again, only the FCR at $1000 \mathrm{mg} \mathrm{L}^{-1} \mathrm{NO}_{3}^{-}-\mathrm{N}$ was significantly increased at $1.1 \mathrm{~g} \mathrm{~g}^{-1} \pm 0.2$ 212 compared to the control ( $\mathrm{P}<0.01$, non-parametric Dunn`s).

\section{Blood parameters}

214 There was an increase in the $\mathrm{NO}_{2}{ }^{-}$- and $\mathrm{NO}_{3}{ }^{-}$- plasma concentrations with increasing nitrate 215 concentration (Fig.3). The maximum increase in plasma concentration of $\mathrm{NO}_{2}^{-}\left(516 \mu \mathrm{M} \mathrm{NO}_{2}^{-} \pm\right.$ 216 284) and $\mathrm{NO}_{3}^{-}(22 \mu \mathrm{M} \pm 2.8)$ was found at an exposure of $1000 \mathrm{mg} \mathrm{L}{ }^{-1} \mathrm{NO}_{3}^{-}-\mathrm{N}(\mathrm{P}<0.01$, non- 
217 parametric Dunn`s), but no statistical analysis was carried out due to low $\mathrm{n}$ in the highest

218 treatment group.

219 Total hemoglobin concentration decreased with increasing $\mathrm{NO}_{3}{ }^{-}$concentration (Fig.4), lowest

220 (3.5 g/dL \pm 0.8$)$ in the $1000 \mathrm{mgL}^{-1} \mathrm{NO}_{3}{ }^{-}-\mathrm{N}$ group $(\mathrm{P}<0.05$, non-parametric Dunn`s). Congruently, 221 an increase of methemoglobin with increasing $\mathrm{NO}_{3}{ }^{-}$concentration (Fig.4) was observed. The

222 highest methemoglobin concentration $(44 \% \pm 9)$ was recorded in the treatment group exposed to

$2231000 \mathrm{mgL}^{-1} \mathrm{NO}_{3}{ }^{-}-\mathrm{N}(\mathrm{P}<0.05$, non-parametric Dunn`s $)$

\section{Hepatosomatic index (HSI)}

225 We observed an increase in HSI with increasing $\mathrm{NO}_{3}{ }^{-}$concentrations (Fig.5). The highest HSI

$226(1.5 \pm 0.5)$ was recorded at $1000 \mathrm{mgL}^{-1} \mathrm{NO}_{3}{ }^{-}-\mathrm{N}$, but no significant differences were detected $(\mathrm{p}<$ 227 0.05, nonparametric Dunn`s).

\section{$228 \quad$ Gill histology}

229 Major abnormalities observed here were hyperplasia of epithelial cells, hyperplasia in cells 230 between the lamellae, hypertrophy of pillar cells, clubbing, hypertrophy of epithelial cells, 231 hypertrophy of mucus cells, fusion of secondary lamella and epithelial lifting (Tab.1). No 232 significant differences were analyzed between treatments, but, as a trend, most abnormalities 233 increased with increasing $\mathrm{NO}_{3}{ }^{-}$concentrations (Tab.1). Congruently, occurrence of undamaged

234 secondary filaments decreased with increasing nitrate concentrations. Above $100 \mathrm{mgL}^{-1} \mathrm{NO}_{3}{ }^{-}-\mathrm{N}$ 235 less than $50 \%$ of the lamellae were undamaged compared to $62 \%$ in the control. A strong 236 increase of hyperplasia in epithelial cells as well as secondary lamella was recorded, particularly 237 in the treatment group exposed to $1000 \mathrm{mgL}^{-1} \mathrm{NO}_{3}{ }^{-} \mathrm{N}$. Hypertrophy of pillar cells was frequently 238 observed (between $20 \%$ at $1000 \mathrm{mg} \mathrm{L}^{-1} \mathrm{NO}_{3}^{-}-\mathrm{N}$ and $56 \%$ at $500 \mathrm{mg} \mathrm{L}^{-1} \mathrm{NO}_{3}^{-}-\mathrm{N}$ ), but revealed 239 high individual variability. In contrast, hypertrophy of mucus and epithelial cell was very low 
$240(<5 \%)$, again irrespective of treatment. Clubbing was equally low $(<10 \%)$ irrespective of

241 treatment. Other abnormalities encompassed less then $5 \%$ of the total damages.

\section{Conversion of nitrate in the stomach of tilapia}

243 We observed a significant conversion of nitrate in the stomach content of Nile tilapia $(p<0.01$,

244 nonparametric Dunn`s, $\mathrm{n}=5$ ). Nitrite already increased after $45 \mathrm{~min}$, but not significantly different 245 compared to $14 \mu \mathrm{M} \mathrm{NO}_{2}{ }^{-}( \pm 2)$ after $5 \mathrm{~min}$. After $90 \mathrm{~min}$, a significant increase up to $74 \mu \mathrm{M} \mathrm{NO}_{2}{ }^{-}$

$246( \pm 14)$ was observed $(\mathrm{p}<0.01$, nonparametric Dunn`s, $n=5)$. No further increase of nitrite was

247 observed after 150 min (Fig.6)

\section{Discussion}

249 The aim of this study was to investigate if chronic exposure to realistic nitrate concentrations 250 observed in RAS (10-1000 $\left.\mathrm{mg} \mathrm{L}^{-1} \mathrm{NO}_{3}^{-}-\mathrm{N}\right)$ induces adverse effects on growth performance, feed

251 conversion or health status in juvenile Nile tilapia and to provide data on safe nitrate 252 concentrations in intensive RAS-based tilapia culture. Mortalities only occurred in the highest 253 treatment group, confirming that the range of concentrations chosen was adequate. Due to 254 coagulation, we did not consider these fish for blood analysis. Directly after sampling, brown 255 colored blood was recorded in fish of the highest treatment group confirming 256 methemoglobinemia in these fish.

257 Both, decreasing SGR and increasing FCR were observed with increasing ambient nitrate 258 concentrations. Still, significant differences to the control were only observed at $1000 \mathrm{mg} \mathrm{L}^{-1}$ $259 \mathrm{NO}_{3}{ }^{-}$-N. In several studies, reduced growth performance was indicative of inadequate water 260 quality in tilapia. For example, Shaw \& Handy (2006) evaluated chronic copper toxicity in Nile 261 tilapia, reporting depression of SGR from 1.58 (control) to 1.2. More pronounced, El-Sherif \& 262 El-Feky (2009) observed a drastic decrease of SGR from 1.16 (control) to 0.53 in tilapia 263 fingerlings during an experiment at $\mathrm{pH}$ 6. Although there are no data on chronic nitrate toxicity in 
264 tilapia, reduced growth as well as increased feed conversion has been observed in other species.

265 For example, van Bussel et al. (2012) reported a significant decrease of SGR from 1.6 to 0.45

266 with increasing nitrate concentration, as well as a significant increase of FCR from 1.07 to 3.80

267 in juvenile turbot (Scophthalmus maximus). In comparison to turbot (van Bussel et al., 2012),

268 pikeperch (Schram, Roques, van Kuijk, Abbunk, van de Heul, de Vries, Bierman, van de Vis \&

269 Flik $(2014$, b) and catfish (Schram et al. 2014, a), results of our study suggest that tilapia is less

270 sensitive, not surprisingly with regard to the habitat of the respective species. Here, a low feeding

271 rate was chosen to assure an optimal water quality. Still, the decrease in SGR observed here is

272 moderate and thus unexpectedly good with regard to the control. Congruently, feed conversion

273 was significantly reduced at $1000 \mathrm{mg} \mathrm{L}^{-1} \mathrm{NO}_{3}{ }^{-} \mathrm{N}$ with an FCR of 1.13 compared to 0.72 in the

274 control. In a study on deleterious sub-lethal ammonia exposure $\left(0.4 \mathrm{mg} \mathrm{L}^{-1} \mathrm{NH}_{3}-\mathrm{N}\right)$ to juvenile

275 Nile tilapia, FCR increased from 1.5 (control) to 8 (El-Shafai, El-Gohary, Nasr, van der Steen \&

276 Gijzen 2004). Here, at an exposure of up to $500 \mathrm{mg} \mathrm{L}^{-1} \mathrm{NO}_{3}{ }^{-} \mathrm{N}$, neither SGR nor FCR were

277 affected. Congruently, no effects on FCR and SGR were reported in pikeperch (Sander

278 lucioperca) at nitrate concentrations up to $358 \mathrm{mg} \mathrm{L}^{-1} \mathrm{NO}_{3}{ }^{-}-\mathrm{N}$ (Schram et al., $2014 \mathrm{~b}$ ).

279 As a conclusion, reduced growth performance and feed conversion could be a consequence of 280 increased energy expenditure required to counteract adverse effects, for example conversion of 281 methemoglobin as later on discussed. Alternatively, growth depression could also arise from 282 nitrate-mediated modulation of the thyroid axis, since nitrate competes with the uptake of iodide 283 in the thyroid (Ward, Kilfoy, Weyer, Anderson, Folsom \& Cerhan 2010). Thereby, formation of 284 thyroid hormones T3 and T4 would be reduced which in turn leads to reduced growth. Still, 285 plasma nitrate observed was low and nitrite much higher, supporting the conclusion that the 286 formation of $\mathrm{MetHb}$ and the subsequent energy expenditure is the primary cause of reduced 287 growth and feed conversion observed here. 
The concentration of nitrate in the plasma samples was well below concentrations in ambient water. Nitrite and nitrate concentrations increased with ambient nitrate concentrations of the

290 rearing water, but, in contrast to Schram et al. $(2014$, a, b), nitrite exceeded the nitrate

291 concentrations in the plasma about 27 fold. Therefore, it seems that there was an uptake of 292 nitrate, whether active or passive, followed by a reduction of nitrate to nitrite within the body of 293 tilapia.

294 Until today, the uptake of nitrate is still poorly understood, mainly due to the fact that most 295 tissues represent a barrier preventing the passage of the large hydrated nitrate ion. In their study 296 on nitrate toxicity to African catfish (Clarias gariepinus) Schram et al. $(2014$, a) concluded that 297 the integument of the fish forms a significant barrier to waterborne nitrate. As a consequence, 298 alternative routes for nitrate uptake are limited and uptake via the gills seems most plausible with 299 regard to the direct contact with the ambient water as well as the importance in osmoregulation 300 and ion uptake (Hwang 2009). However, a low permeability for nitrate through the gills was 301 discussed in trout (Stormer et al. 1996) and has been reported in freshwater crayfish (Jensen 302 1996). In contrast, nitrite uptake has been described for the gills as well as the intestinal wall. For 303 example, Grosell \& Jensen (2000) documented nitrite passage over the intestinal/stomach wall of 304 the European flounder and nitrite uptake in the stomach is very fast in rats (Bryan, Fernandez, 305 Bauer, Garcia-Saura, Milsom, Rassaf, Maloney, Bharti, Rodriguez \& Feelisch 2005). 306 Additionally, nitrite and chloride compete for the active branchial chloride uptake mechanism in 307 freshwater fish (Williams \& Eddy, 1986), and since the chloride concentration in freshwater is 308 low, the presence of nitrite can lead to massive nitrite accumulation in the plasma (Grosell \& 309 Jensen, 2000). Furthermore, low stability of nitrite suggests rather acetic conditions to prevent 310 fast oxidation. 
311 Consequently we hypothesized that uptake involves a reduction of nitrate to nitrite in the

312 stomach, prior to the actual passage of the intestinal wall. Such route would result in high plasma

313 nitrite, similar to those observed here. Therefore, we assessed the reduction of nitrate to nitrite in

314 stomach juice in an in vitro experiment. We demonstrate that nitrate is rapidly converted into

315 nitrite reaching a maximum of $74 \mu \mathrm{M} \mathrm{NO}_{2}^{-}$after $90 \mathrm{~min}$. Our findings strongly indicate that

316 conversion of nitrate to nitrite in the gastro-intestinal system of tilapia represents the most

317 probable uptake route. As a consequence, nitrate toxicity in tilapia is mainly a result of nitrate

318 reduction to nitrite and irreversible oxidation of hemoglobin to methemoglobin. Nevertheless,

319 nitrate is quite stable ( 8 h, Webb, Patel, Loukogeorgakis, Okorie, About, Misra, Rashid, Miall,

320 Deanfield, Benjamin, MacAllister, Hobbs \& Ahluwalia 2008) and anaerobic conversion of nitrate

321 to nitrite in the gut needs to be considered (Webb et al. 2008; Speijers \& van den Brandt 2003;

322 Fanning 2000).

323 In this experiment, observations, which are typically attributed to nitrite toxicity, furthermore

324 confirm nitrite mediated intoxication. At 500 and $1000 \mathrm{mg} \mathrm{L}^{-1} \mathrm{NO}_{3}^{-}-\mathrm{N}$, formation of

325 methemoglobin was $22.5 \%( \pm 14.1)$ and $43.9 \%( \pm 9.3)$, respecitvely. At lower concentrations,

326 methemoglobin was low, ranging between $8.9 \%$ and $16.5 \%$. Considering the actual nitrite

327 concentrations from $23.9 \mu \mathrm{M}\left(0 \mathrm{mg} \mathrm{L}^{-1} \mathrm{NO}_{3}{ }^{-} \mathrm{N}\right)$ to $65.3 \mu \mathrm{M}\left(100 \mathrm{mg} \mathrm{L}^{-1} \mathrm{NO}_{3}^{-}{ }^{-} \mathrm{N}\right)$ in the plasma,

328 counteracting mechanisms seem to restore homeostasis until an ambient concentration of at least

$329100 \mathrm{mg} \mathrm{L}^{-1} \mathrm{NO}_{3}{ }^{-}-\mathrm{N}$. Here, methemoglobin reductase converts methemoglobin to hemoglobin and

330 restores functionality of red blood cells, but also represents a substantial energy expenditure

331 (Choury, Leroux \& Kaplan, 1981). Therefore, a decrease in SGR is most likely a result of

332 increasing methemoglobin formation and its energy demanding recycling. The presence of

333 around $10 \%$ methemoglobin in the blood as observed between $0 \mathrm{mg} \mathrm{L}^{-1} \mathrm{NO}_{3}^{-}-\mathrm{N}$ and $100 \mathrm{mg} \mathrm{L}^{-1}$

$334 \mathrm{NO}_{3}{ }^{-} \mathrm{N}$ are within the range reported as basic level in other species (Kroupova, Machova \& 
335 Svobodova 2005; Wuertz et al. 2013). A visible indicator for severe methemoglobinemia is the

336 formation of brown colored blood, which in Nile tilapia is first observed at approximately $20 \%$

337 of methemoglobin with no other symptoms of toxcicity (Svobodova, Machova, Poleszczuk,

338 Huda, Hamackova \& Kroupova 2005). Here, brown color was observed during sampling of the

339 highest treatment group at $33.9 \%-52.2 \%$ methemoglobin. Levels above 50\% methemoglobin

340 are considered threatening to fish (Bowser, Falls, Vanzandt, Collier, \& Phillips 1983), which

341 clearly identifies $\mathrm{NO}_{3}^{-}-\mathrm{N} \geq 1000 \mathrm{mg} \mathrm{L}^{-1}$ as intolerable for the rearing of juvenile Nile tilapia. We

342 further recorded a significantly elevated HSI (Fig.5) at $1000 \mathrm{mg} \mathrm{L}^{-1} \mathrm{NO}_{3}^{-}{ }^{-} \mathrm{N}$ which indicates other

343 adverse effects on the liver. Since nitrite is an oxidizing agent this finding may indicate increased

344 oxidative stress, but further studies are needed. Still, detoxification mechanisms to cope with

345 oxidative stress as well as elevated nitrite include enhanced turnover by catalase and cytochrome

346 c oxidase (summarized by Kroupova et al. 2005), which often lead to increased liver metabolism

347 and, subsequently, liver size. These processes are energy demanding and will hence further

348 reduce growth performance and increase FCR.

349 As gills comprise the largest surface in direct contact with the surrounding water (Evans,

350 Piermarini \& Choe 2005) and subsequently represent the organ most heavily exposed,

351 abnormalities such as fusion of the secondary lamellae have been regarded as defense mechanism

352 limiting the uptake of toxins (Reiser, Schroeder, Wuertz, Kloas \& Hanel 2010). Although some

353 histopathological changes have been recorded in the gills, high individual variation was observed

354 here. With regard to the low brachial permeability of nitrate, such lower incidence of gill

355 abnormalities seems plausible. Nevertheless, a decreasing trend of undamaged secondary

356 filaments from the control group to the highest treatment group was recorded (Tab.1). We also

357 observed increased hyperplasia of the epithelial cells as well as cells of the secondary lamella in

358 the highest treatment group, which are typically regarded as mild responses to increase the 
359 diffusion barrier towards toxins in the water, compared to strong ones such as fusion of the

360 lamella.

361 To our knowledge this investigation is the first one demonstrating that high nitrate 362 concentrations, realistic for commercial RAS, impact juvenile tilapia at high concentrations of

$363500 \mathrm{mgL}^{-1} \mathrm{NO}_{3}^{-}-\mathrm{N}$ and $1000 \mathrm{mgL}^{-1} \mathrm{NO}_{3}{ }^{-} \mathrm{N}$. Thus, tilapia is relatively robust towards nitrate and

364 subsequent nitrite toxification. Here, no significant impacts on growth performance, feed

365 conversion and health status were observed between $10 \mathrm{mgL}^{-1} \mathrm{NO}_{3}^{-}{ }^{-} \mathrm{N}$ and $500 \mathrm{mgL}^{-1} \mathrm{NO}_{3}^{-}-\mathrm{N}$

366 Once more, it has been shown, that tilapia is well suited for intensive RAS-based aquaculture, but

367 nutrient management such as decoupled aquaponics can improve animal health and welfare and 368 production effectiveness.

\section{Acknowlegements}

371 We would like to thank Susanne and Petra for their help during the study. Thomas Mehner 372 provided helpful advice on the first draft of the manuscript. Hendrik Monsees was funded with a 373 scholarship of the Elsa-Neumann-Stiftung (Berlin, Germany).

\section{References}

Bowser, P. R., Falls, W. W., Vanzandt, J., Collier, N. \& Phillips, J. D. (1983) Methemoglobinemia in Channel Catfish - Methods of prevention. Progressive FishCulturist 45, 154-158.

Bryan, N. S., Fernandez, B. O., Bauer, S. M., Garcia-Saura, M. F., Milsom, A. B., Rassaf, T., Maloney, R. E., Bharti, A., Rodriguez, J. \& Feelisch, M. (2005) Nitrite is a signaling molecule and regulator of gene expression in mammalian tissues. Nature Chemical Biology 1, 290-7.

Camargo, J. A., Alonso, A. \& Salamanca, A. (2005) Nitrate toxicity to aquatic animals: a review with new data for freshwater invertebrates. Chemosphere 58, 1255-1267. 
Cheng, S.-Y. \& Chen, J.-C. (2002) Study on the oxyhemocyanin, deoxyhemocyanin, oxygen affinity and acid-base balance of Marsupenaeus japonicus following exposure to combined elevated nitrite and nitrate. Aquatic Toxicology 61, 181-193.

Choury, D., Leroux, A. \& Kaplan, J. C. (1981) Membrane-bound cytochrome b5 reductase (methemoglobin reductase) in human erythrocytes. Study in normal and methemoglobinemic subjects. Journal of Clinical Investigation 67 149-155.

Colt, J. \& Tchobanoglous, G. (1976) Evaluation of the short-term toxicity of nitrogenous compounds to channel catfish, Ictalurus punctatus. Aquaculture 8, 209-224.

Davidson, J., Good, C., Welsh, C. \& Summerfelt, S. T. (2014) Comparing the effects of high vs. low nitrate on the health, performance, and welfare of juvenile rainbow trout Oncorhynchus mykiss within water recirculating aquaculture systems. Aquacultural Engineering 59, 30-40.

Dekov, V. M., Komy, Z., Araujo, F., Van Put, A. \& Van Grieken, R. (1997) Chemical composition of sediments, suspended matter, river water and ground water of the Nile (Aswan-Sohag traverse). Science of the Total Environment 201, 195-210.

Edwards, T. M. Miller, H. D.; Guillette, L. J. (2006) Water quality influences reproduction in female mosquitofish (Gambusia holbrooki) from eight Florida springs Environmental Health Perspectives 114, 69-75.

El-Shafai, S. A., El-Gohary, F. A., Nasr, F. A., Van Der Steen, N. P. \& Gijzen, H. J. (2004) Chronic ammonia toxicity to duckweed-fed tilapia (Oreochromis niloticus). Aquaculture 232, $117-127$.

El-Sherif, M. S. \& El-Feky, A. M. I. (2009) Performance of Nile tilapia (Oreochromis niloticus) fingerlings. I. Effect of pH. International. Journal of. Agriculture and Biology 11, 297300 .

Eskiocak, S., Dundar, C., Basoglu, T. \& Altaner, S. (2005) The effects of taking chronic nitrate by drinking water on thyroid functions and morphology. Clinical and Experimental Medicine 5, 66-71.

Evans, D. H., Piermarini, P. M. \& Choe, K. P. (2005) The multifunctional fish gill: dominant site of gas exchange, osmoregulation, acid-base regulation, and excretion of nitrogenous waste. Physiological reviews $\mathbf{8 5}, 97-177$.

Fanning, J. C. (2000) The chemical reduction of nitrate in aqueous solution. Coordination Chemistry Reviews 199, 159-179.

Fao (2014) Oreochromis niloticus - Cultured Aquatic Species Information Programme. http://www.fao.org/fishery/culturedspecies/Oreochromis_niloticus/en. (accessed: 30.11.2014) 
Freitag, A. R., Thayer, L. R., Leonetti, C., Stapleton, H. M. \& Hamlin, H. J. (2015) Effects of elevated nitrate on endocrine function in Atlantic salmon, Salmo salar. Aquaculture 436, $8-12$.

Grosell, M. \& Jensen, F. B. (2000) Uptake and effects of nitrite in the marine teleost fish Platichthys flesus. Aquatic Toxicology 50, 97-107.

Gutierrez-Wing, M. T. \& Malone, R. F. (2006) Biological filters in aquaculture: Trends and research directions for freshwater and marine applications. Aquacultural Engineering 34, 163-171.

Hamlin, H. J., Moore, B. C., Edwards, T. M., Larkin, I. L. V., Boggs, A., High, W. J., Main, K. L. \& Guillette Jr, L. J. (2008) Nitrate-induced elevations in circulating sex steroid concentrations in female Siberian sturgeon (Acipenser baeri) in commercial aquaculture. Aquaculture 281, 118-125.

Hegesh, E., Gruener, N., Cohen, S., Bochkovsky, R. \& Shuval, H. I. (1970) A sensitive micromethod for the determination of methemoglobin in blood. Clinica Chimica Acta 30, 679-682.

Hwang, P.-P. (2009) Ion uptake and acid secretion in zebrafish (Danio rerio). Journal of Experimental Biology 212, 1745-1752.

Jensen, F. B. (1996) Uptake, elimination and effects of nitrite and nitrate in freshwater crayfish (Astacus astacus). Aquatic Toxicology 34, 95-104.

Komy, Z. R. \& El-Samahy, A. A. (1995) Dissolved Ions of Trace and Major Elements and in Suspended Sediments in the Nile, Egypt. Chemistry and Ecology 11, 25-37.

Kroupova, H., Machova, J. \& Svobodova, Z. (2005) Nitrite influence on fish: a review. Veterinarni Medicina 50, 461-471.

Lattauschke, G. (2004) Anbau von Gewächshausgemüse: Hinweise zum umweltgerechten Anbau - Managementunterlage. Sächsische Landesanstalt für Landwirtschaft 2nd edition p.220, Dresden, Germany.

Lutz, I., Kloas, W., Springer, T., Holden, L., Wolf, J., Krueger, H. \& Hosmer, A. (2008) Development, standardization and refinement of procedures for evaluating effects of endocrine active compounds on development and sexual differentiation of Xenopus laevis. Analytical and Bioanalytical Chemistry 390, 2031-2048.

Monteiro, S. M., Rocha, E., Fontainhas-Fernandes, A. \& Sousa, M. (2008) Quantitative histopathology of Oreochromis niloticus gills after copper exposure. Journal of Fish Biology 73, 1376-1392.

Rakocy, J. E., Masser, M. P. \& Losordo, T. M. (2006) Recirculating Aquaculture Tank Production Systems: Aquaponics-Integrating Fish and Plant Culture. Southern Regional Aquaculture Center 1-16. 
Reiser, S., Schroeder, J., Wuertz, S., Kloas, W. \& Hanel, R. (2010) Histological and physiological alterations in juvenile turbot (Psetta maxima, L.) exposed to sublethal concentrations of ozone-produced oxidants in ozonated seawater. Aquaculture 307, 157 164.

Schram, E., Roques, J. a. C., Abbink, W., Yokohama, Y., Spanings, T., De Vries, P., Bierman, S., Van De Vis, H. \& Flik, G. $(2014$, a) The impact of elevated water nitrate concentration on physiology, growth and feed intake of African catfish Clarias gariepinus (Burchell 1822). Aquaculture Research 45, 1499-1511.

Schram, E., Roques, J. a. C., Van Kuijk, T., Abbink, W., Van De Heul, J., De Vries, P., Bierman, S., Van De Vis, H. \& Flik, G. $(2014$, b) The impact of elevated water ammonia and nitrate concentrations on physiology, growth and feed intake of pikeperch (Sander lucioperca). Aquaculture 420-421, 95-104.

Scott, G. \& Crunkilton, R. L. (2000) Acute and chronic toxicity of nitrate to fathead minnows (Pimephales promelas), Ceriodaphnia dubia, and Daphnia magna. Environmental Toxicology and Chemistry 19, 2918-2922.

Shaw, B. J. \& Handy, R. D. (2006) Dietary copper exposure and recovery in Nile tilapia, Oreochromis niloticus. Aquatic Toxicology 76 111-121.

Speijers, G. J. A. \& Van Den Brandt, P. A. 2003. Nitrite and Potential Endogenous Formation of N-Nitroso Compounds. WHO Food Additives Series: 50 Geneva: World Health Organization.

Stormer, J., Jensen, F. B. \& Rankin, J. C. (1996) Uptake of nitrite, nitrate, and bromide in rainbow trout, Oncorhynchus mykiss: Effects on ionic balance. Canadian Journal of Fisheries and Aquatic Sciences 53, 1943-1950.

Svobodova, Z., Machova, J., Poleszczuk, G., Huda, J., Hamackova, J. \& Kroupova, H. (2005) Nitrite poisoning of fish in aquaculture facilities with water-recirculating systems. Acta Veterinaria Brno 74, 129-137.

Timmons, M. B., Holder, J. L. \& Ebeling, J. M. (2006) Application of microbead biological filters. Aquacultural Engineering 34, 332-343.

Tomasso, J. R. \& Carmichael, G. J. (1986) Acute toxicity of ammonia, nitrite, and nitrate to the guadalupe bass, Micropterus treculi. Bulletin of Environmental Contamination and Toxicology 36, 866-870.

Van Bussel, C. G. J., Schroeder, J. P., Wuertz, S. \& Schulz, C. (2012) The chronic effect of nitrate on production performance and health status of juvenile turbot (Psetta maxima). Aquaculture 326-329, 163-167.

Van Rijn, J. 2010. Denitrification. In: TIMMONS, M. B., EBELING, J.M. (ed.) Recirculating Aquaculture, second ed. NewYork: 769 p. Cayuga Aqua Ventures . 
Van Rijn, J. (2013) Waste treatment in recirculating aquaculture systems. Aquacultural Engineering 53, 49-56.

Ward, M. H., Kilfoy, B. A., Weyer, P. J., Anderson, K. E., Folsom, A. R. \& Cerhan, J. R. (2010) Nitrate Intake and the Risk of Thyroid Cancer and Thyroid Disease. Epidemiology (Cambridge, Mass.) 21, 389-395.

Webb, A. J., Patel, N., Loukogeorgakis, S., Okorie, M., Aboud, Z., Misra, S., Rashid, R., Miall, P., Deanfield, J., Benjamin, N., Macallister, R., Hobbs, A. J. \& Ahluwalia, A. (2008) Acute Blood Pressure Lowering, Vasoprotective, and Antiplatelet Properties of Dietary Nitrate via Bioconversion to Nitrite. Hypertension 51, 784-790.

Westin, D. T. (1974) Nitrate and Nitrite Toxicity to Salmonoid Fishes. The Progressive FishCulturis, 36, 86-89.

Williams, E. M. \& Eddy, F. B. Chloride uptake in freshwater teleosts and its relationship to nitrite uptake and toxicity. Journal of Comparative Physiology B 156, 867-872.

Wuertz, S., Schulze, S. G. E., Eberhardt, U., Schulz, C. \& Schroeder, J. P. (2013) Acute and chronic nitrite toxicity in juvenile pike-perch (Sander lucioperca) and its compensation by chloride. Comparative Biochemistry and Physiology C-Toxicology \& Pharmacology $157352-360$.

Zimmermann-Timm, H. 2011. Versalzung von Gewässern. In: Warnsignal Klima: Wasser für alle? Vol. 3 Ed. Lozán, J.L.; Graßl, H.; Karbe, L.; Hupfer, P.; Schönwiese, C.-D. p 580. Climate Service Center, Germany 


\section{Figure captions}

564 Fig. 1: Specific growth rate (SGR, mean \pm SD) in juvenile Nile tilapia Oreochromis niloticus

565 after $30 \mathrm{~d}$ of exposure to $0,10,100,500$ and $1000 \mathrm{mg} \mathrm{L}^{-1} \mathrm{NO}_{3}{ }^{-}-\mathrm{N}$. Significant differences to the 566 control are indicated by an asterisk ( $\mathrm{p}<0.01$, non-parametric Dunn's). The number of samples is

567 indicated on top of each column. SGR $=(\ln$ final weight $-\ln$ start weight $) /$ days $* 100$

Fig. 2: Feed conversion ratio (FCR, mean $\pm \mathrm{SD}$ ) in juvenile Nile tilapia Oreochromis niloticus after $30 \mathrm{~d}$ of exposure to $0,10,100,500$ and $1000 \mathrm{mg} \mathrm{L}^{-1} \mathrm{NO}_{3}{ }^{-}-\mathrm{N}$. Significant differences to the control are indicated by an asterisk ( $\mathrm{p}<0.01$, non-parametric Dunn's). The number of samples is indicated on top of each column. FCR= dry weight feed/ (final wet weight - initial wet weight)

573

574

Fig. 3: Plasma $\mathrm{NO}_{2}{ }^{-}$and $\mathrm{NO}_{3}{ }^{-}$(mean $\pm \mathrm{SD}$ ) in juvenile Nile tilapia Oreochromis niloticus after 30 $\mathrm{d}$ of exposure to $0,10,100,500$ and $1000 \mathrm{mg} \mathrm{L}^{-1} \mathrm{NO}_{3}{ }^{-} \mathrm{N}$. Significant differences to the control are indicated by asterisk ( $\mathrm{p}<0.01$, non-parametric Dunn's). The number of samples is indicated on top of each column. No statistical analysis was conducted in the highest treatment group for plasma $\mathrm{NO}_{3}{ }^{-}$due to a low number of replicates.

Fig. 4: Hemoglobin and methemoglobin concentrations (mean \pm SD) in the blood of juvenile Nile tilapia Oreochromis niloticus after $30 \mathrm{~d}$ of exposure to $0,10,100,500$ and $1000 \mathrm{mg} \mathrm{L}^{-1} \mathrm{NO}_{3}{ }^{-} \mathrm{N}$. Significant differences to the control are indicated by asterisk ( $\mathrm{p}<0.05$, non-parametric Dunn's). The number of samples is indicated on top of each column.

Fig. 5: Hepatosomatic index (HSI, mean \pm SD) in juvenile Nile tilapia Oreochromis niloticus after $30 \mathrm{~d}$ of exposure to $0,10,100,500$ and $1000 \mathrm{mg} \mathrm{L}^{-1} \mathrm{NO}_{3}{ }^{-} \mathrm{N}$. No significant differences were detected ( $\mathrm{p}<0.05$, nonparametric Dunn`s). The number of samples is indicated on top of each column. HSI = (liver weight $/$ final weight of fish $) * 100$

590 Fig. 6: Conversion of nitrate (nominal concentration: $1000 \mathrm{mg} \mathrm{L}^{-1} \mathrm{NO}_{3}{ }^{-} \mathrm{N}$ ) to nitrite in the gastric juice of Nile tilapia after incubation at room temperature. Presented are the means $( \pm S D, n=5)$. 
592 Significant differences to the start of the incubation (after 5 min) are indicated by asterisks

$593(\mathrm{p}<0.01$, non-parametric Dunn's $)$

594

595

596

597

598

599

600

601

602

603 